\title{
Evaluation of Salivary Gland Lesions by Fine Needle Aspiration Cytology at a Tertiary Care Hospital, Western Nepal
}

This article was published in the following Dove Press journal: Pathology and Laboratory Medicine International

\author{
Anuj Poudel (D) \\ Bigya Shrestha \\ Sudeep Regmi \\ 'Department of Pathology, Universal \\ College of Medical Sciences, Bhairahawa, \\ Nepal; ${ }^{2}$ Department of Pathology, \\ Hospital for Advanced Medicine \& \\ Surgery (HAMS), Kathmandu, Nepal; \\ ${ }^{3}$ Department of Pathology, Manipal \\ College of Medical Sciences, Pokhara, \\ Nepal
}

Background: Salivary gland tumors (SGTs) account for $2-6.5 \%$ of all head and neck neoplasms, and fine needle aspiration cytology (FNAC) is one of the most useful diagnostic methods for clinicians. FNAC is utilized for evaluating suspicious salivary gland lesions initially. This study was undertaken to evaluate the various cytomorphological features of non-neoplastic and neoplastic lesions of salivary gland as diagnosed by FNAC.

Materials and Methods: This prospective, analytical study was done for a period of 18 months from January 1, 2014 to June 31, 2016 at the Universal College of the Medical Sciences Teaching Hospital (UCMS-TH), Bhairahawa, Nepal. A total of 81 FNAC samples were collected from patients with salivary gland swelling. The lesions were evaluated cytologically and correlations with histopathological follow-up data were acquired in 31 cases. All statistical analyses were performed utilizing Statistical Package for Social Sciences (SPSS) software (version 24). Sensitivity and specificity of FNAC were evaluated and compared to that of biopsy.

Results: Out of the 81 cases studied, females of 21-30 years of age were the most commonly affected. The most common site of involvement was the parotid gland, with a frequency of $66.7 \%$, the predominant benign lesion diagnosed cytologically was pleomorphic adenoma (PA), with a frequency of $51.84 \%$, and the most common malignant lesion diagnosed was mucoepidermoid carcinoma (MEC), with a frequency of $9.88 \%$. Of the total $(\mathrm{N}=81), 19.75 \%$ were of pediatric and $80.25 \%$ were in the adult age group. Within the pediatric age group, all the lesions diagnosed by FNAC were benign, with the most common lesion being PA. In the total cases evaluated for FNAC, biopsy sample was collected from 31 cases for histological correlation, with $90.32 \%$ corroborating the FNAC diagnosis.

Conclusion: The study demonstrated that FNAC is a very useful, rapid, and minimally invasive diagnostic tool for salivary gland lesions that can be utilized for subsequent therapeutic case management.

Keywords: fine needle aspiration cytology, FNAC, salivary gland lesions, Nepal

\section{Introduction}

There are three pairs of major SGs (Parotid, Submandibular, and Sublingual glands) and in the submucosa of the oral cavity occur many minor salivary glands. ${ }^{1}$ The causes of salivary gland swelling are different, like inflammatory process, cysts, or tumors, and often it is difficult to point out whether the swelling is arising from salivary gland proper or from adjacent structures such as lymph nodes, soft tissues, or skin. ${ }^{2}$
Correspondence: Anuj Poudel Universal College of Medical Sciences, Bhairahawa, Nepal

Email dranujpoudel@gmail.com 
Out of all head and neck tumors, salivary gland tumors account for 2-6.5\%, and FNAC is the main diagnostic tool in evaluation due to its superficial location, easy accessibility, and high diagnostic accuracy. ${ }^{3,4}$ FNAC in suspected salivary gland swelling can confirm the origin, whether its preauricular or submandibular lymph node, which can mimic clinically as salivary gland neoplasm and also provides the nature of the disease process for a proper management plan. $^{5}$ Therefore, FNAC is also a superior diagnostic tool as compared to incisional biopsy, where a risk of tumor implantation and fistula formation can encounter. ${ }^{1}$

The purpose of the study was to understand the varied cytomorphological patterns of salivary gland lesions and to compare the results of clinical and FNAC in the diagnosis of the salivary gland lesions in the patients attending UCMS-TH, Bhairahawa, Nepal.

\section{Methodology}

A hospital-based analytical study was conducted for a period of 18 months from January 1, 2015 to July 31, 2016 at the Department of Pathology (DOP) in collaboration with the Department of Ear Nose and Throat (ENT) at the UCMS-TH, Bhairahawa, Nepal. In total, 81 samples were collected during the study period. All patients with salivary gland swelling after clinical examination from the ENT referred to the DOP for FNAC were included in the study. Relevant patient history about salivary gland swelling was obtained. The clinical diagnosis provided in the requisition form was categorized as: No specific diagnosis, PA, Chronic Sialadenitis (CS), Malignant Tumor (MT), Benign Cystic Lesion (BCL), and Acute Sialadenitis (AS). For each patient in the study, the site, size, consistency, and tenderness were evaluated, and FNAC performed. The nature of the aspirated material was recorded in the patient record, fixed in slides, and stained with Giemsa and Papanicolaou stain and microscopically observed for cytological diagnosis. The observed FNAC diagnosis was correlated with clinical diagnosis provided in the patient record.

In the cases involving surgery, the excised tissues were received in the DOP. The surgical specimens received were properly examined with gross details, appropriate sections from various parts of the excised tissues were taken and processed to prepare Hematoxylin and Eosin (H\&E) stained slides. To evaluate the efficacy of FNAC in salivary gland lesions, slides were examined and the histopathological diagnosis was correlated with the diagnosis of FNAC.

Written medical records were maintained with the details about the study cases. Informed written consent was taken from the adult patients and among the pediatric age group patients consent was taken from the respective parents. The Institutional Review Board (IRB), Universal College of Medical Sciences and Teaching Hospital, Bhairahawa, Nepal provided the ethical clearance to conduct the study and the statistical analysis was performed by utilizing "Statistical Package for Social Service" (SPSS) version 24.0 software. Sensitivity and specificity of FNAC were evaluated and compared to that of biopsy.

\section{Results}

Among the 81 patients who underwent FNAC of salivary glands during the study period, the most common age group involved was adults between 21-30 years $(27.16 \%)$ and $31-40$ years $(17.28 \%)$ and the pediatric age group between $11-20$ years (13.58\%). The youngest patient was 8 years of age and the oldest was 78 years of age, with a mean of age of $36.89 \pm 18.97$ years. In total, 42 $(51.85 \%)$ were female, and 39 (48.15\%) were male, yielding a Male:Female (M:F) ratio of 1:1.33.

The most common site of FNAC was the parotid gland, with a frequency of $66.5 \%$, followed by the Submandibular gland (33.5\%). The right side was more commonly involved in comparison to the left, with frequencies of $61.65 \%$ and $38.35 \%$, respectively (Figure 1).

The most commonly diagnosed lesion on FNAC was PA of $42(51.84 \%)$ cases followed by BCL of 11 (13.58\%) cases. Out of all PA, 34 (41.98\%) cases were located in the Parotid gland and the remaining eight $(9.88 \%)$ cases were located in the Sub-mandibular gland. The most common

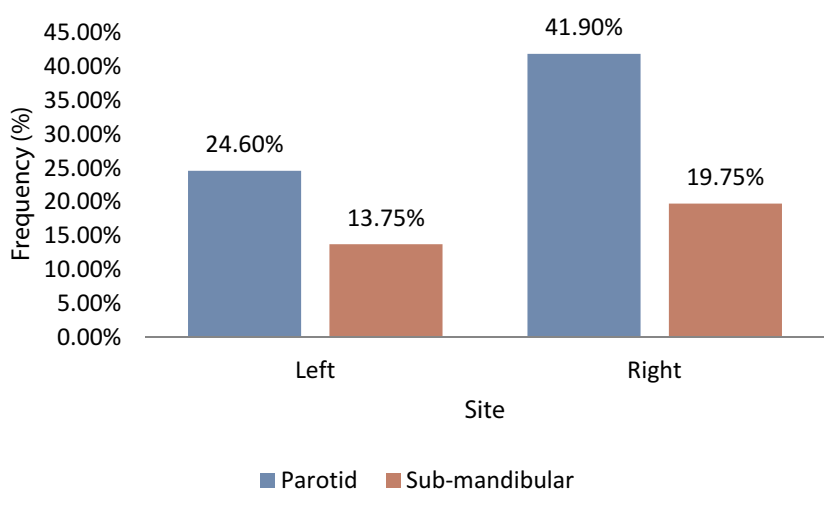

Figure I Frequency of FNACs according to the site and laterality $(\mathrm{N}=8 \mathrm{I})$. 
Table I FNAC Diagnosis of Salivary Gland Lesions According to Site $(N=8 I)$

\begin{tabular}{|c|c|c|c|}
\hline \multirow[t]{2}{*}{ FNAC Diagnosis } & \multicolumn{2}{|l|}{ Site } & \multirow{2}{*}{$\begin{array}{l}\text { Total } \\
\text { No. (\%) }\end{array}$} \\
\hline & $\begin{array}{l}\text { Parotid } \\
\text { No. (\%) }\end{array}$ & $\begin{array}{l}\text { Sub-Mandibular } \\
\text { No. (\%) }\end{array}$ & \\
\hline Acute Sialadenitis & $0(0)$ & I (I.23\%) & $\mathrm{I}(\mathrm{I} .23 \%)$ \\
\hline Chronic Sialadenitis & $2(2.47 \%)$ & 4 (4.94\%) & $6(7.41 \%)$ \\
\hline Benign Cystic Lesion & $6(7.41 \%)$ & $5(6.17 \%)$ & II (I3.58\%) \\
\hline Pleomorphic Adenoma & 34 (4I.98\%) & $8(9.88 \%)$ & $42(51.84 \%)$ \\
\hline Warthin's Tumor & $2(2.47 \%)$ & I (I.23\%) & $3(3.71 \%)$ \\
\hline Acinic Cell Carcinoma & $3(3.71 \%)$ & I (I.23\%) & $4(4.94 \%)$ \\
\hline Mucoepidermoid Carcinoma & $5(6.17 \%)$ & $3(3.71 \%)$ & 8 (9.88\%) \\
\hline Adenoid Cystic Carcinoma & $0(0.00 \%)$ & $3(3.71 \%)$ & $3(3.71 \%)$ \\
\hline Carcinoma ex Pleomorphic Adenoma & I (I.23\%) & $0(0.00 \%)$ & $\mathrm{I}(\mathrm{I} .23 \%)$ \\
\hline Sialadenosis & $\mathrm{I}(\mathrm{I} .23 \%)$ & $\mathrm{I}(\mathrm{l} .23 \%)$ & $2(2.47 \%)$ \\
\hline Total & 54 (66.67\%) & 27 (33.33\%) & 81 (100\%) \\
\hline
\end{tabular}

malignant lesion diagnosed on FNAC was MEC, comprising of eight $(9.88 \%)$ cases (Table 1$)$.

Out of 81 cases referred for FNAC, 15 cases had no specific clinical diagnosis provided. In the 45 cases that were clinically diagnosed with PA, 42 cases were diagnosed as PA on FNAC. In 11 cases of clinically diagnosed CS, six cases exhibited the same diagnosis with FNAC. In one case of malignant tumor diagnosed clinically, a similar result was obtained on FNAC. Out of eight cases of BCL diagnosed clinically, seven cases revealed the same diagnosis on FNAC. Both clinical diagnosis and FNAC exhibited the same result in the case of $\mathrm{AC}(\mathrm{n}=1)$. Of all the salivary gland lesions $(\mathrm{N}=81)$, there was concordance in $57(70.37 \%)$ of the cases between their clinical and FNAC diagnosis (Table 2)

In the total 81 cases, the pediatric population (age group $\leq 20$ years) made up $16(19.75 \%)$ cases and the remaining $65(80.25 \%)$ cases were adults (age group $>20$ ). Among the pediatric population, all were diagnosed as benign lesions by FNAC, in which PA was the most common lesion (six cases), followed by BCL (four cases), and CS (three cases). Eleven pediatric cases fall in the age group 11-20 years and five cases fall in the age group $<10$ years. Among the adult population, 16 cases were diagnosed as malignant lesions, in which MEC was most common (eight cases), followed by ACC (four cases), and AdCC (three cases). Only one case was diagnosed as Carcinoma Ex pleomorphic adenoma. Among 49 benign lesions in the adult age group, PA was the most common, with 36 cases, followed by BCL in seven cases (Table 3).

Out of the 81 cases in the study, only $31(38.28 \%)$ cases underwent biopsy for histopathological evaluation
(HPE). There was concordance in $28(90.32 \%)$ of the cases between FNAC diagnosis and their histology (Table 4).

The microscopic pictures of the most common lesions (Pleomorphic adenoma and Mucoepidermoid carcinoma) are shown in Figures 2-4.

\section{Discussion}

SGTs represent a diverse group of neoplasm. The incidence of these tumors worldwide is between $0.05-2 /$ 100,000 population. ${ }^{6}$ Salivary gland tumors constitute about $0.5 \%$ of all cancers and $5 \%$ of head and neck malignancy. ${ }^{7}$ In the present study, FNAC of salivary gland lesions were performed in 81 cases and showed a variety of non-neoplastic and neoplastic lesions in different locations amongst patients of different ages and sex. The youngest patient was 8 years of age and the oldest was 78 years of age, with the mean age of $36.89 \pm 18.97$ years (mean $\pm \mathrm{SD}$ ). The most common age group involved was 21-30 years, with a frequency of $27.16 \%$. Similar figures were noted in the studies conducted by Jain et al, ${ }^{8-10}$

In this study, the number of affected females $(51.85 \%)$ was more than that of males $(48.15 \%)$ with a $\mathrm{M}: \mathrm{F}$ ratio of $1: 1.33$. While Bhagavath et al, ${ }^{10-14}$ showed male preponderance. This suggests that the sex predilection variations may be linked to many complex environmental and personal factors which are yet to be established and requires further investigations. One such study, conducted by McKenna et al, ${ }^{15}$ assumed that radiation therapy of the head and neck was an etiological factor for causation of benign and malignant salivary gland lesions. The parotid gland was found to 
Table 2 Association Between Clinical and FNAC Diagnosis $(\mathrm{N}=8 \mathrm{I})$

\begin{tabular}{|c|c|c|c|c|c|c|c|c|}
\hline & & \multicolumn{7}{|l|}{ Clinical Diagnosis } \\
\hline & & $\begin{array}{l}\text { No Specific } \\
\text { Diagnosis Provided }\end{array}$ & $\begin{array}{l}\text { Pleomorphic } \\
\text { Adenoma }\end{array}$ & $\begin{array}{l}\text { Chronic } \\
\text { Sialadenitis }\end{array}$ & $\begin{array}{l}\text { Malignant } \\
\text { Tumor }\end{array}$ & $\begin{array}{l}\text { Benign } \\
\text { Cystic } \\
\text { Lesion }\end{array}$ & $\begin{array}{l}\text { Acute } \\
\text { Sialadenitis }\end{array}$ & Total \\
\hline \multirow{12}{*}{$\begin{array}{l}\text { FNAC } \\
\text { Diagnosis }\end{array}$} & & No (\%) & No (\%) & No (\%) & No (\%) & No (\%) & No (\%) & No (\%) \\
\hline & AS & $0(0.00 \%)$ & $0(0.00 \%)$ & $0(0.00 \%)$ & $0(0.00 \%)$ & $0(0.00 \%)$ & I (I.23\%) & I (1.23\%) \\
\hline & CS & $0(0.00 \%)$ & $0(0.00 \%)$ & 6 (7.4I\%) & $0(0.00 \%)$ & $0(0.00 \%)$ & $0(0.00 \%)$ & $6(7.41 \%)$ \\
\hline & $\mathrm{BCL}$ & $0(0.00 \%)$ & I (I.23\%) & 3 (3.7I\%) & $0(0.00 \%)$ & 7 (8.65\%) & $0(0.00 \%)$ & II (I3.58\%) \\
\hline & PA & $0(0.00 \%)$ & 42 (5I.85\%) & $0(0.00 \%)$ & $0(0.00 \%)$ & $0(0.00 \%)$ & $0(0.00 \%)$ & $42(51.85 \%)$ \\
\hline & WT & $2(2.47 \%)$ & I (I.23\%) & $0(0.00 \%)$ & $0(0.00 \%)$ & $0(0.00 \%)$ & $0(0.00 \%)$ & $3(3.71 \%)$ \\
\hline & ACC & 4 (4.94\%) & $0(0.00 \%)$ & $0(0.00 \%)$ & $0(0.00 \%)$ & $0(0.00 \%)$ & $0(0.00 \%)$ & 4 (4.94\%) \\
\hline & MEC & $5(6.17 \%)$ & I (I.23\%) & $0(0.00 \%)$ & I (I.23\%) & I (I.23\%) & $0(0.00 \%)$ & $8(9.88 \%)$ \\
\hline & AdCC & 3 (3.7।\%) & $0(0.00 \%)$ & $0(0.00 \%)$ & $0(0.00 \%)$ & $0(0.00 \%)$ & $0(0.00 \%)$ & 3 (3.7।\%) \\
\hline & CaexPA & I (I.23\%) & $0(0.00 \%)$ & $0(0.00 \%)$ & $0(0.00 \%)$ & $0(0.00 \%)$ & $0(0.00 \%)$ & I (1.23\%) \\
\hline & SA & $0(0.00 \%)$ & $0(0.00 \%)$ & 2 (2.47\%) & $0(0.00 \%)$ & $0(0.00 \%)$ & $0(0.00 \%)$ & $2(2.47 \%)$ \\
\hline & Total & 15 (I8.52\%) & 45 (55.54\%) & II (13.58\%) & $\mathrm{I}(\mathrm{I} .23)$ & $8(9.88 \%)$ & $\mathrm{I}(\mathrm{I} .23 \%)$ & 81 (100\%) \\
\hline
\end{tabular}

Abbreviations: AS, acute sialadenitis; CS, chronic sialadenitis; BCL, benign cystic lesion; PA, pleomorphic adenoma; WT, Warthin's tumor; ACC, acinic cell carcinoma; MEC, mucoepidermoid carcinoma; AdCC, adenoid cystic carcinoma; CaexPA, carcinoma ex pleomorphic adenoma; SA, sialadenosis.

be the most common site of FNAC (66.66\%) of all the salivary gland lesions in the present study, followed by the submandibular gland (33.34\%). This finding was similar to the studies conducted by UlAan et $\mathrm{al}^{16,17}$ and Devi et al, but according to Vaidya et al, ${ }^{18}$ the submandibular gland was the most common site. For all lesions, the right side was the most favored laterality for the occurrence of salivary gland lesions in this study. Lesions involving the sublingual gland were not observed in this study, which was in accordance with study done by Vuhahula, ${ }^{19}$ but showed discordance with the study done by Bahra et $a{ }^{20}{ }^{20}$ where $7 \%$ of the cases involved the sublingual glands. Another study done by Mejia-Velazquez et $\mathrm{al}^{21}$ also demonstrated that $1 / 319$ lesions involved the sublingual gland. Thus, the site of lesion varies according to the nature of the lesion, age of the patient, geographical, and racial factors. ${ }^{19}$

In the total 81 cases, the pediatric population (age group $\leq 20$ years) made up $16(19.75 \%)$ cases and the remaining $65(80.25 \%)$ cases were adults (age group $>20$ ). Among the pediatric population, all were diagnosed as benign lesions by FNAC, in which PA was the most common lesion (six cases), followed by BCL (four cases), and CS (three cases), which is not similar to the study done by Ronchi et al, ${ }^{22}$ in which malignant lesions were observed in the pediatric age group.

Among the benign lesions in the 81 cases, the most commonly diagnosed lesion in our study was Pleomorphic Adenoma, with a frequency of $51.84 \%$, which is similar to the studies by Vaidya et al, ${ }^{18}$ and Tahoun and Ezzat. ${ }^{23}$ and Tahoun and Ezzat. ${ }^{24}$ Among the malignant lesions, Mucoepidermoid Carcinoma was the most common finding, with a frequency of $9.88 \%$, which is in accordance with studies done by Piccioni et al, ${ }^{25-28}$

This study observed an agreement of $70.37 \%$ between clinical and FNAC diagnosis, which was similar to a study done by Schmidt et al. ${ }^{29}$

Among the 81 cases of salivary gland neoplasms in the present study, only $31(38.28 \%)$ of the cases underwent biopsy for histopathological evaluation. Out of these 31 (38.28\%) biopsies, two of the $11(13.58 \%)$ benign cystic lesions were available for histopathological correlation, both of which showed discrepancies. The histological diagnoses for these lesions were chronic sialadenitis and Mucoepidermoid carcinoma (intermediate grade) each. This may be due to a sampling error where the needle 
Table 3 FNAC Diagnosis According to Age Distribution ( $\mathrm{N}=8 \mathrm{I})$

\begin{tabular}{|c|c|c|c|c|c|c|c|c|c|c|}
\hline & \multicolumn{10}{|c|}{ Age Group } \\
\hline & & $\begin{array}{l}<1-10 \\
\text { years }\end{array}$ & $\begin{array}{l}I I-20 \\
\text { years }\end{array}$ & $\begin{array}{l}21-30 \\
\text { years }\end{array}$ & $\begin{array}{l}3 I-40 \\
\text { years }\end{array}$ & $\begin{array}{l}41-50 \\
\text { years }\end{array}$ & $\begin{array}{l}5 I-60 \\
\text { years }\end{array}$ & $\begin{array}{l}61-70 \\
\text { years }\end{array}$ & $\begin{array}{l}>70 \\
\text { years }\end{array}$ & Total \\
\hline \multirow[t]{11}{*}{$\begin{array}{l}\text { FNA } \\
\text { Diagnosis }\end{array}$} & AS & $0(0.00 \%)$ & $\begin{array}{l}0 \\
(0.00 \%)\end{array}$ & $\begin{array}{l}0 \\
(0.00 \%)\end{array}$ & $\begin{array}{l}0 \\
(0.00 \%)\end{array}$ & $\begin{array}{l}\text { I } \\
(1.23 \%)\end{array}$ & $\begin{array}{l}0 \\
(0.00 \%)\end{array}$ & $\begin{array}{l}0 \\
(0.00 \%)\end{array}$ & $\begin{array}{l}0 \\
(0.00 \%)\end{array}$ & $\begin{array}{l}\mathrm{I} \\
(1.23 \%)\end{array}$ \\
\hline & CS & $\begin{array}{l}3 \\
(3.7 \mid \%)\end{array}$ & $\begin{array}{l}0 \\
(0.00 \%)\end{array}$ & $\begin{array}{l}\text { I } \\
\text { (1.23\%) }\end{array}$ & $\begin{array}{l}0 \\
(0.00 \%)\end{array}$ & $\begin{array}{l}\text { I } \\
(1.23 \%)\end{array}$ & $\begin{array}{l}\text { I } \\
\text { (1.23\%) }\end{array}$ & $\begin{array}{l}0 \\
(0.00 \%)\end{array}$ & $\begin{array}{l}0 \\
(0.00 \%)\end{array}$ & $\begin{array}{l}6 \\
(7.41 \%)\end{array}$ \\
\hline & $\mathrm{BCL}$ & $\begin{array}{l}1 \\
(1.23 \%)\end{array}$ & $\begin{array}{l}3 \\
(3.71 \%)\end{array}$ & $\begin{array}{l}\text { I } \\
(1.23 \%)\end{array}$ & $\begin{array}{l}2 \\
(2.47 \%)\end{array}$ & $\begin{array}{l}1 \\
(1.23 \%)\end{array}$ & $\begin{array}{l}0 \\
(0.00 \%)\end{array}$ & $\begin{array}{l}\text { I } \\
(1.23 \%)\end{array}$ & $\begin{array}{l}2 \\
(2.47 \%)\end{array}$ & $\begin{array}{l}\text { II } \\
(13.58 \%)\end{array}$ \\
\hline & PA & $\begin{array}{l}0 \\
(0.00 \%)\end{array}$ & $\begin{array}{l}6 \\
(7.41 \%)\end{array}$ & $\begin{array}{l}17 \\
(21.00 \%)\end{array}$ & $\begin{array}{l}10 \\
(12.33 \%)\end{array}$ & $\begin{array}{l}3 \\
(3.71 \%)\end{array}$ & $\begin{array}{l}3 \\
(3.7 \mid \%)\end{array}$ & $\begin{array}{l}3 \\
(3.7 \mid \%)\end{array}$ & $\begin{array}{l}0 \\
(0.00 \%)\end{array}$ & $\begin{array}{l}42 \\
(51.84 \%)\end{array}$ \\
\hline & WT & $\begin{array}{l}0 \\
(0.00 \%)\end{array}$ & $\begin{array}{l}\text { I } \\
\text { (I.23\%) }\end{array}$ & $\begin{array}{l}0 \\
(0.00 \%)\end{array}$ & $\begin{array}{l}0 \\
(0.00 \%)\end{array}$ & $\begin{array}{l}\mathrm{I} \\
(1.23 \%)\end{array}$ & $\begin{array}{l}0 \\
(0.00 \%)\end{array}$ & $\begin{array}{l}0 \\
(0.00 \%)\end{array}$ & $\begin{array}{l}\text { I } \\
\text { (1.23\%) }\end{array}$ & $\begin{array}{l}3 \\
(3.71 \%)\end{array}$ \\
\hline & $A C C$ & $\begin{array}{l}0 \\
(0.00 \%)\end{array}$ & $\begin{array}{l}0 \\
(0.00 \%)\end{array}$ & $\begin{array}{l}\text { I } \\
(1.23 \%)\end{array}$ & $\begin{array}{l}\text { I } \\
(1.23 \%)\end{array}$ & $\begin{array}{l}0 \\
(0.00 \%)\end{array}$ & $\begin{array}{l}2 \\
(2.47 \%)\end{array}$ & $\begin{array}{l}0 \\
(0.00 \%)\end{array}$ & $\begin{array}{l}0 \\
(0.00 \%)\end{array}$ & $\begin{array}{l}4 \\
(4.94 \%)\end{array}$ \\
\hline & MEC & $\begin{array}{l}0 \\
(0.00 \%)\end{array}$ & $\begin{array}{l}0 \\
(0.00 \%)\end{array}$ & $\begin{array}{l}\text { I } \\
(1.23 \%)\end{array}$ & $\begin{array}{l}\text { I } \\
(1.23 \%)\end{array}$ & $\begin{array}{l}\text { I } \\
(1.23 \%)\end{array}$ & $\begin{array}{l}2 \\
(2.47 \%)\end{array}$ & $\begin{array}{l}\text { I } \\
\text { (1.23\%) }\end{array}$ & $\begin{array}{l}2 \\
(2.47 \%)\end{array}$ & $\begin{array}{l}8 \\
(9.88 \%)\end{array}$ \\
\hline & AdCC & $\begin{array}{l}0 \\
(0.00 \%)\end{array}$ & $\begin{array}{l}0 \\
(0.00 \%)\end{array}$ & $\begin{array}{l}\text { I } \\
(1.23 \%)\end{array}$ & $\begin{array}{l}0 \\
(0.00 \%)\end{array}$ & $\begin{array}{l}0 \\
(0.00 \%)\end{array}$ & $\begin{array}{l}\text { I } \\
\text { (1.23\%) }\end{array}$ & $\begin{array}{l}\text { I } \\
(1.23 \%)\end{array}$ & $\begin{array}{l}0 \\
(0.00 \%)\end{array}$ & $\begin{array}{l}3 \\
(3.71 \%)\end{array}$ \\
\hline & CaexPA & $\begin{array}{l}0 \\
(0.00 \%)\end{array}$ & $\begin{array}{l}0 \\
(0.00 \%)\end{array}$ & $\begin{array}{l}0 \\
(0.00 \%)\end{array}$ & $\begin{array}{l}0 \\
(0.00 \%)\end{array}$ & $\begin{array}{l}\text { I } \\
(1.23 \%)\end{array}$ & $\begin{array}{l}0 \\
(0.00 \%)\end{array}$ & $\begin{array}{l}0 \\
(0.00 \%)\end{array}$ & $\begin{array}{l}0 \\
(0.00 \%)\end{array}$ & $\begin{array}{l}1 \\
(1.23 \%)\end{array}$ \\
\hline & SA & $\begin{array}{l}1 \\
(1.23 \%)\end{array}$ & $\begin{array}{l}\text { I } \\
(1.23 \%)\end{array}$ & $\begin{array}{l}0 \\
(0.00 \%)\end{array}$ & $\begin{array}{l}0 \\
(0.00 \%)\end{array}$ & $\begin{array}{l}0 \\
(0.00 \%)\end{array}$ & $\begin{array}{l}0 \\
(0.00 \%)\end{array}$ & $\begin{array}{l}0 \\
(0.00 \%)\end{array}$ & $\begin{array}{l}0 \\
(0.00 \%)\end{array}$ & $\begin{array}{l}2 \\
(2.47 \%)\end{array}$ \\
\hline & Total & $\begin{array}{l}5 \\
(6.17 \%)\end{array}$ & $\begin{array}{l}11 \\
(13.58 \%)\end{array}$ & $\begin{array}{l}22 \\
(27.16 \%)\end{array}$ & $\begin{array}{l}14 \\
(17.29 \%)\end{array}$ & $\begin{array}{l}9 \\
\text { (11.11\%) }\end{array}$ & $\begin{array}{l}9 \\
\text { (II.II\%) }\end{array}$ & $\begin{array}{l}6 \\
(7.41 \%)\end{array}$ & $\begin{array}{l}5 \\
(6.17 \%)\end{array}$ & $\begin{array}{l}81 \\
(100 \%)\end{array}$ \\
\hline
\end{tabular}

Abbreviations: AS, acute sialadenitis; CS, chronic sialadenitis; BCL, benign cystic lesion; PA, pleomorphic adenoma; WT, Warthin's tumor; ACC, acinic cell carcinoma; MEC, mucoepidermoid carcinoma; AdCC, adenoid cystic carcinoma; CaexPA, carcinoma ex pleomorphic adenoma; SA, sialadenosis.

might have hit only the cystic area, which is similar to the study done by Kumar et al. ${ }^{30}$ Postema et al ${ }^{31}$ also observed similar findings when diagnosing cystic lesions.

A total of $42(51.85 \%)$ cases were diagnosed as Pleomorphic adenoma cytologically. Twenty-one $(25.92 \%)$ of them were available for histopathological evaluation; all of them correlated with FNAC diagnosis. Eight of the MEC cases were cytologically diagnosed, out of which cyto-histopathological correlation was present in six cases. All these cases were histologically confirmed as low-grade and intermediate MEC. This correlation of MEC is similar to the findings of the study done by Tessy et al. ${ }^{32}$ The main diagnostic criteria used for cytological diagnosis of MEC are variation in cell type predominantly intermediate cells, mucin-secreting cells, infrequently squamous epithelial cells with relatively bland nuclei, and some prominent nucleoli in a dirty background of mucus and debris. ${ }^{33}$

The diagnostic dilemma in the cytological diagnosis of salivary gland lesions has been seen in cystic mucus-containing lesions, which shows similar features on smears of Warthin's tumor, sialadenitis, and low-grade mucoepidermoid carcinoma. Thus, cytologic evaluation may be difficult if the smears contain only a few cells, as stated by Tani and Skoog. ${ }^{34}$ In our study also, one cytologically diagnosed BCL was later diagnosed as chronic sialadenitis in histopathology, and the other case of cytologically diagnosed BCL was diagnosed as MEC, intermediate grade histologically. This is attributed to the lack of cellularity for proper evaluation of the lesion leading to an erroneous diagnosis on FNA. The study showed that the number of variables including cellularity, architecture, epithelial components and 
Table 4 Association of FNAC Diagnosis with Biopsy $(n=31)$

\begin{tabular}{|c|c|c|c|c|c|c|}
\hline \multicolumn{2}{|c|}{ FNAC Diagnosis $(\mathbf{N}=\mathbf{8} I)$} & \multicolumn{5}{|c|}{ Biopsy Correlation } \\
\hline & & \multirow{2}{*}{$\begin{array}{l}\text { PA } \\
\text { No. } \\
0\end{array}$} & \multirow{2}{*}{$\begin{array}{l}\text { MEC } \\
\text { No. } \\
0\end{array}$} & \multirow{2}{*}{$\begin{array}{l}\text { CS } \\
\text { No. } \\
0\end{array}$} & \multirow{2}{*}{$\begin{array}{l}\text { AdCC } \\
\text { No. } \\
0\end{array}$} & \multirow{2}{*}{$\begin{array}{l}\text { No of Biopsies Done } \\
(n=31)\end{array}$} \\
\hline AS & 1 & & & & & \\
\hline CS & 6 & 0 & 0 & 0 & 0 & 0 \\
\hline $\mathrm{BCL}$ & II & 0 & I & I & 0 & 2 \\
\hline PA & 42 & 21 & 0 & 0 & 0 & 21 \\
\hline WT & 3 & 0 & 0 & 0 & 0 & 0 \\
\hline $\mathrm{ACC}$ & 4 & 0 & 0 & 0 & 0 & 0 \\
\hline MEC & 8 & 0 & 6 & 0 & 0 & 6 \\
\hline AdCC & 3 & 1 & 0 & 0 & I & 2 \\
\hline CaexPA & 1 & 0 & 0 & 0 & 0 & 0 \\
\hline SA & 2 & 0 & 0 & 0 & 0 & 0 \\
\hline Total & 81 & 22 & 7 & I & I & 31 \\
\hline \multicolumn{7}{|c|}{ Sensitivity of FNAC: $90.32 \%$, Specificity of FNAC: $75 \%$} \\
\hline Positive & & W & $0 \%$ & & & \\
\hline
\end{tabular}

Abbreviations: AS, acute sialadenitis; CS, chronic sialadenitis; BCL, benign cystic lesion; PA, pleomorphic adenoma; WT, Warthin's tumor; ACC, acinic cell carcinoma; MEC, mucoepidermoid carcinoma; AdCC, adenoid cystic carcinoma; CaexPA, carcinoma ex pleomorphic adenoma; SA, sialadenosis.

their pleomorphism, myoepithelial cells, oncocytes, stromal matrix, inflammatory cells infiltrates and background were significantly essential for the FNAC diagnosis and categorization of the salivary gland lesions. Similar cytomorphological variables were included in the study conducted by Kocjan and Shah, ${ }^{35-37}$ for the cytological diagnosis of salivary gland lesions.
Three of the cases were diagnosed as AdCC cytologically. Two of them were provided for histological confirmation of the diagnosis. One case showed similar diagnosis on HPE, whereas the other one was diagnosed as PA. The possibility of missing the diagnosis of PA could be due to the presence of single cell dispersion, stromal fragments with spindled cells, and the absence of a cylindromatous pattern.

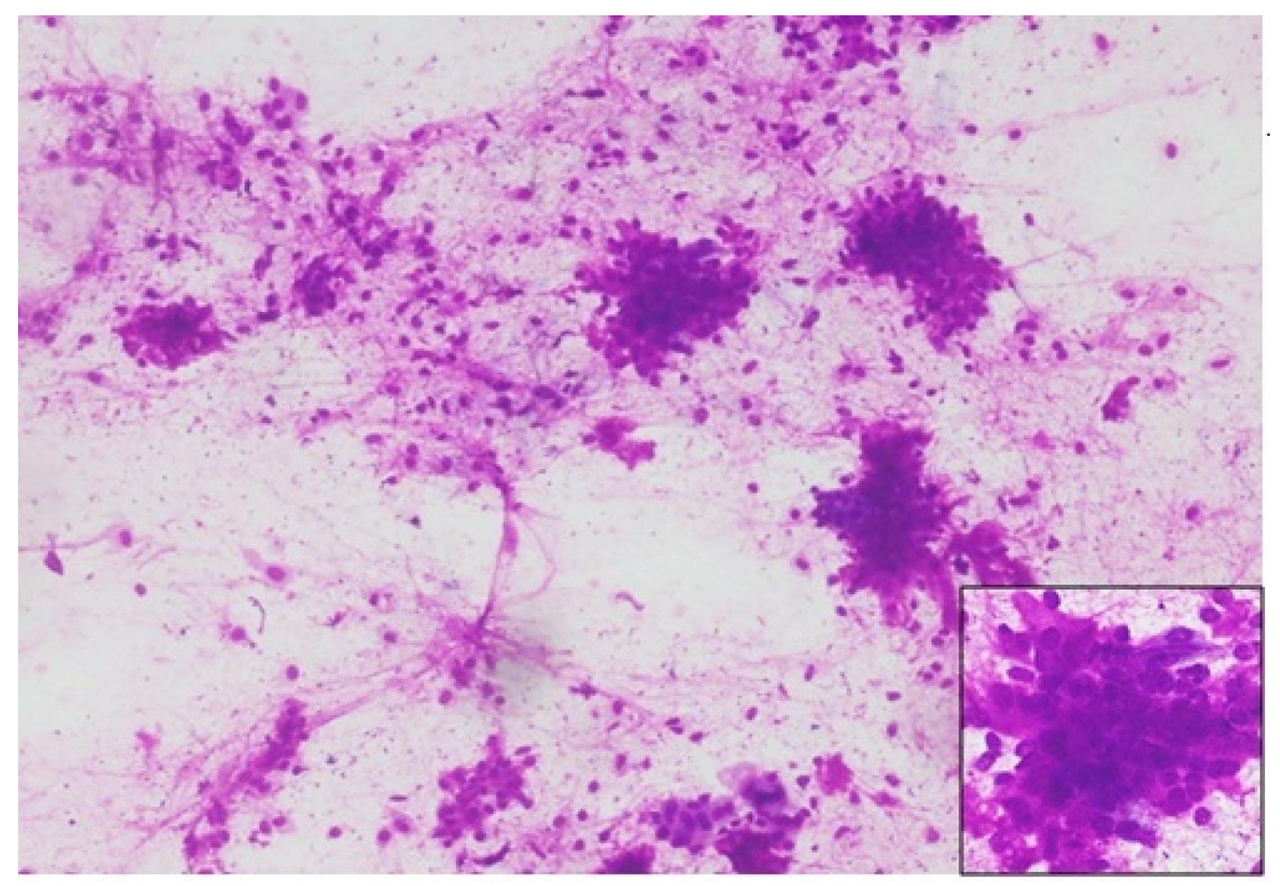

Figure 2 Pleomorphic adenoma (Giemsa stain, 100x). Inset showing epithelial cells (400x). 


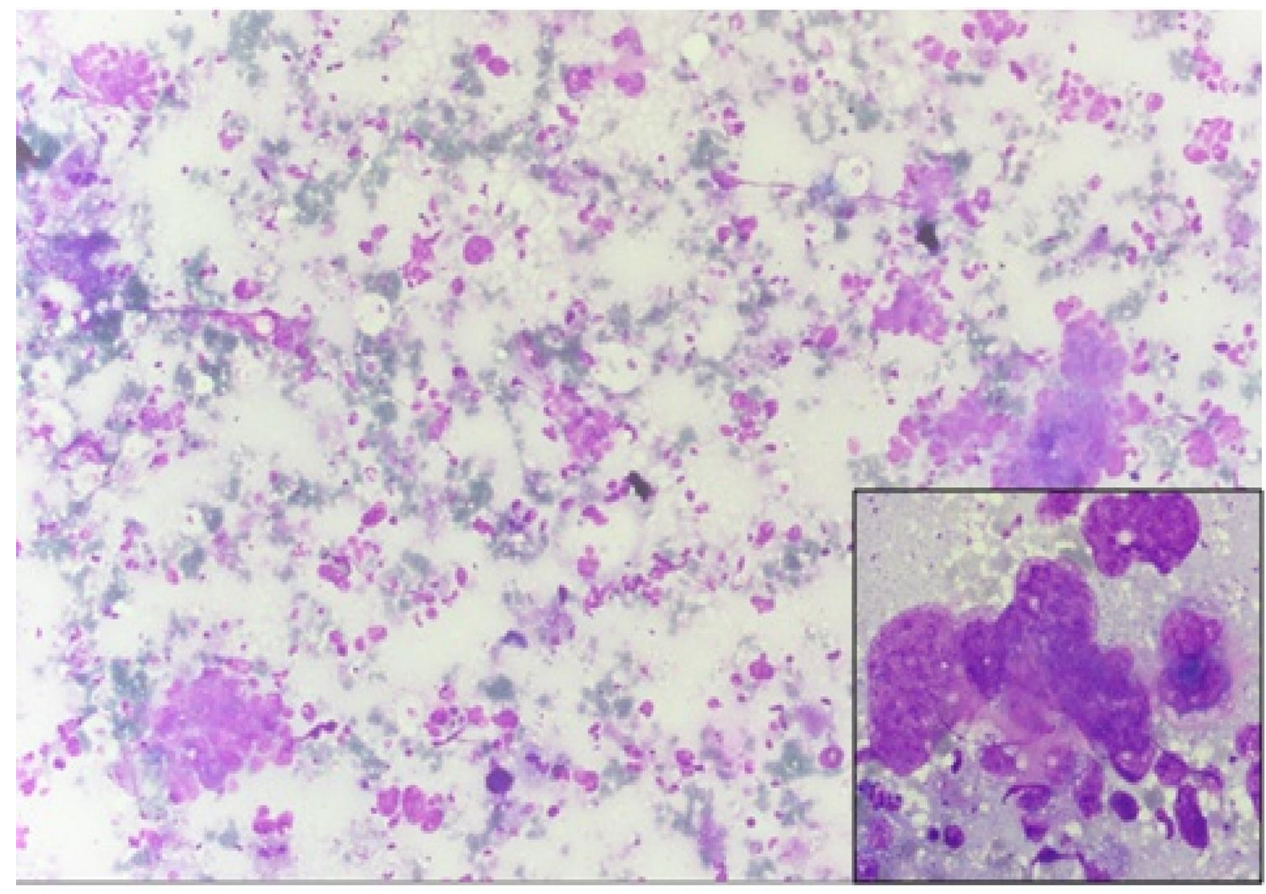

Figure 3 Mucoepidermoid carcinoma (Giemsa, 100x). Inset showing mucin filled cells (400x).

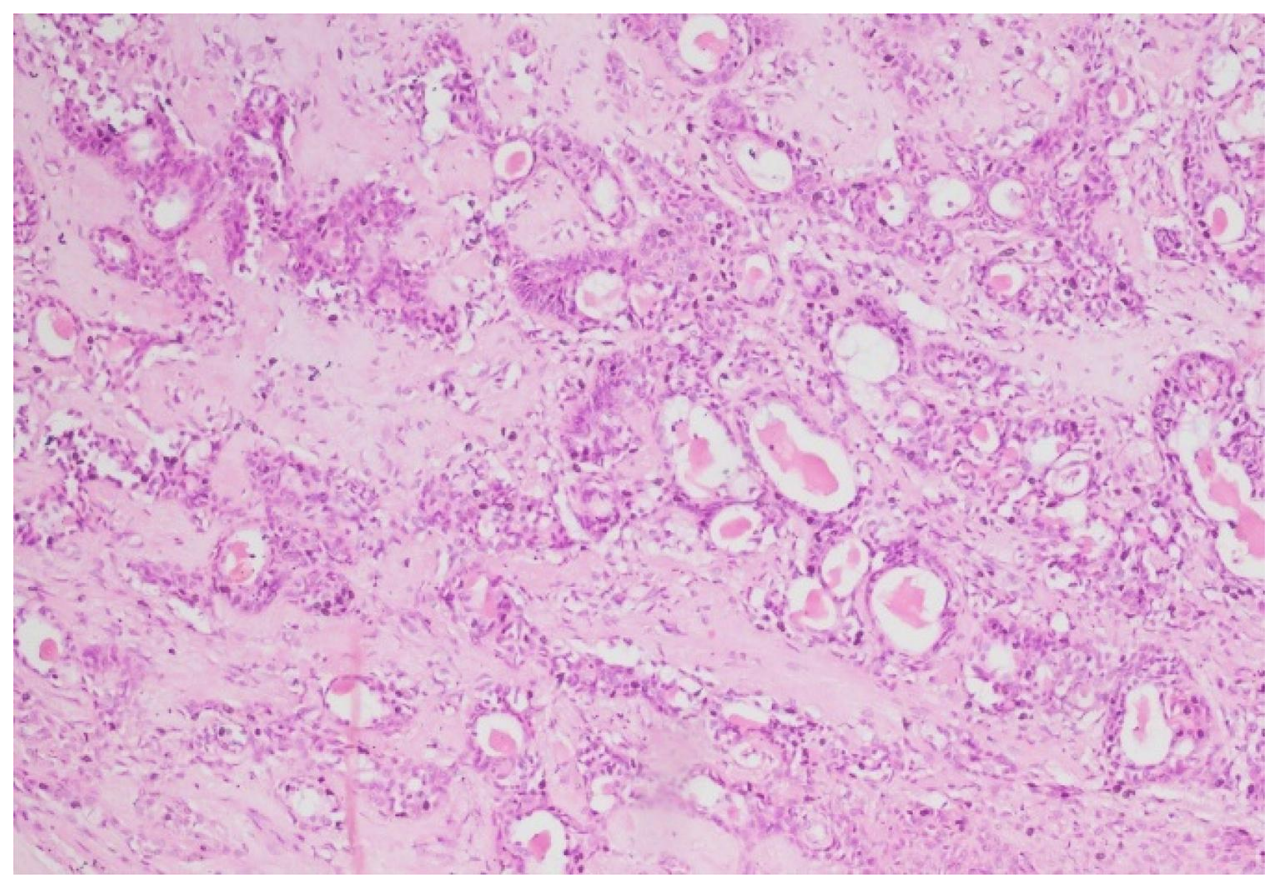

Figure 4 Pleomorphic adenoma (H\&E, 100x).

The studies done by Klijanienko et $\mathrm{al}^{38}$ and Handa et $\mathrm{al}^{39}$ also revealed discrepancies on cytologically diagnosed AdCC on HPE. As stated by Jo et al, ${ }^{40}$ the major causes of diagnostic discrepancies were due to inadequate sampling, poor cellularity and lack of typical cytomorphology related to degenerative changes. 


\section{Conclusion}

FNAC of the salivary gland is now an established, accurate, and highly reliable procedure for the evaluation of the salivary gland lesions. It has significant diagnostic value in differentiating neoplastic from non-neoplastic lesions and offers valuable information for planning and subsequent disease management. However, there were some limitations encountered while predicting specific lesions on cytology, especially when dealing with cystic and some malignant lesions. The aforementioned limitation can be overcome by re-examination of these cases by further histopathological evaluation.

\section{Abbreviations}

ACC, Acinic Cell Carcinoma; AdCC, Adenoid Cystic Carcinoma; AS, Acute Sialadenitis; BCA, Basal Cell Adenoma; CaExPA, Carcinoma Ex Pleomorphic Adenoma; CS, Chronic Sialadenitis; EMCa, Epithelial Myoepithelial Carcinoma; FNAC, Fine Needle Aspiration Cytology; HG, Hyaline Globules; MEC, Mucoepidermoid Carcinoma; PA, Pleomorphic Adenoma; SA, Sialadenosis; SG, Salivary Gland; USG, Ultrasonography; WHO, World Health Organization; WT, Warthin's Tumor.

\section{Data Sharing Statement}

The raw data will be available on request.

\section{Ethical Approval and Consent to Participate}

The ethical approval for study was taken from the Institutional Review committee, Universal College of Medical Sciences, Bhairahawa, Nepal (Registration no: UCMS/IRC/027/2015). Written informed consent was taken from adult patients and among the pediatric patients informed consent was taken from the respective parents before sample collection.

\section{Acknowledgments}

We are grateful to the staff and faculty members of the Universal College of Medical Sciences, Bhairahawa for their support and coordination to accomplish the study. We express our gratitude to all the patients providing samples for the study.

\section{Author Contributions}

All authors made substantial contributions to the conception and design, acquisition of data, or analysis and interpretation of data; took part in drafting the article or revising it critically for important intellectual content; agreed to submit to the current journal; gave final approval of the version to be published; and agree to be accountable for all aspects of the work.

\section{Disclosure}

The authors report no conflicts of interest in this work.

\section{References}

1. Gandhi SH, Purohit TM, Purohit MB, Jethwani D, Vidja M. FNAC diagnosis of salivary gland lesions with histopathological correlation. Natl J Integr Res Med. 2013;4(3):70-77.

2. Fernandes H, D'souza CR, Khosla C, George L, Katte NH. Role of FNAC in the preoperative diagnosis of salivary gland lesions. $J$ Clin Diagn Res JCDR. 2014;8(9):FC01. doi:10.7860/JCDR/2014/ 6788.3956

3. Brennan PA, Davies B, Poller D, et al. Fine needle aspiration cytology (FNAC) of salivary gland tumours: repeat aspiration provides further information in cases with an unclear initial cytological diagnosis. Br J Oral Maxillofac Surg. 2010;48(1):26-29. doi:10.1016/j. bjoms.2008.12.014

4. Parmar MD, Suri SK, Ghoghari DV. Role of fine needle aspiration cytology in salivary glands lesions. J Res Med Dent Sci. 2014;2 (3):23-27. doi: $10.5455 / \mathrm{jrmds} .2014236$

5. Naz S, Hashmi AA, Khurshid A, et al. Diagnostic role of fine needle aspiration cytology (FNAC) in the evaluation of salivary gland swelling: an institutional experience. BMC Res Notes. 2015;8:101. doi:10.1186/s13104-015-1048-5

6. Thiagarajan S, Nair VS, Joshi P, Chaturvedi P. A review of Salivary gland Neoplasms and its management. Online J Otolaryngol. 2014;4(3):41.

7. Eveson JW, Auclair P, Gnepp DR, EL- Naggar AK. Tumors of the salivary glands. In: Barnes L, Eveson JW, editors. WHO Classification of Head and Neck Tumors. IARC; 2002:210-281.

8. Jain R, Gupta R, Kudesia M, Singh S. Fine needle aspiration cytology in diagnosis of salivary gland lesions: a study with histologic comparison. Cyto J. 2013;10. http://www.ncbi.nlm.nih.gov/pmc/arti cles/PMC3623452/.

9. Gupta R, Dewan D, Kumar D, Suri J. Fine-needle aspiration cytology (FNAC) of salivary gland lesions with histopathological correlation in a district hospital of Jammu region. Indian J Pathol Oncol. 2016;3 (1):32-37. doi:10.5958/2394-6792.2016.00008.9

10. Bhagavath P. Role of FNAC in diagnosing salivary gland lesions. Int J AJ Inst Med Sci. 2012;1(2):118-124.

11. Rajdeo RN, Shrivastava AC, Bajaj J, Shrikhande AV, Rajdeo RN Clinicopathological study of salivary gland tumors: an observation in tertiary hospital of central India. 2015. Available from: http://imsear. li.mahidol.ac.th/handle/123456789/166321. Accessed July 24, 2016.

12. Rajbhandari M, Dhakal P, Shrestha S, et al. The correlation between fine needle aspiration cytology and histopathology of head and neck lesions in Kathmandu University Hospital. Kathmandu Univ Med J. 2015;11(4):296-299. doi:10.3126/kumj.v11i4.12525

13. Sangeetha N, Karthika V, Latha S Cytological analysis of salivary gland lesions with histopathological correlation. Available from: http://citeseerx.ist.psu.edu/viewdoc/download?doi=10.1.1.455. 9341\&rep=rep1\&type=pdf. Accessed July 24, 2016.

14. Arumalla A, Pappu KP. Clinico-pathological profile of major salivary gland tumors. Available from: http://ujconline.net/wp-content/ uploads/2013/09/12-UJMDS-15250-Rs.pdf. Accessed July 25, 2016.

15. McKenna RJ. Tumors of the major and minor salivary glands.CA. Cancer J Clin. 1984;34(1):24-39. doi:10.3322/canjclin.34.1.24

16. UlAan N, Tanwani AK. Pitfalls in salivary gland fine-needle aspiration cytology. Int J Pathol. 2009;7(2):61.

17. Devi J, Talukdar KL Salivary gland neoplasms: A clinicopathological study of 84 cases. 2015. Available from: http://imsear.li.mahidol.ac. th/handle/123456789/164586. Accessed July 25, 2016. 
18. Vaidya S, Sinha A, Narayan S, Adhikari S, Sabira KC. A comparative study of fine-needle aspiration cytology and histopathology in salivary gland lesions. J Pathol Nepal. 2011;1(2):108-113. doi:10.3126/ jpn.v1i2.5403

19. Vuhahula EA. Salivary gland tumors in Uganda: clinical pathological study. Afr Health Sci. 2004;Apr(1):15-23.

20. Bahra J, Butt F, Dimba E, Macigo F Patterns of salivary tumours at a university teaching hospital in Kenya. 2012. Available from: http:// file.scirp.org/Html/8-1460186_25260.htm. Accessed July 24, 2016

21. Mejía-Velázquez CP, Durán-Padilla MA, Gómez-Apo E, QuezadaRivera D, Gaitán-Cepeda LA. Tumors of the salivary gland in Mexicans. A retrospective study of 360 cases. Med Oral Patol Oral CirugiaBucal. 2012;17(2):e183. doi:10.4317/medoral.17434

22. Ronchi A, Montella M, Zito Marino F, et al. Diagnostic accuracy of FNA cytology for diagnosis of salivary gland tumors in pediatric patients. Cancer Cytopathol. 2019;127(8):529-538. doi:10.1002/ cncy. 22162

23. Koirala S, Sayami G, Pant AD. Correlation of FNAC and histopathology in diagnosis of salivary gland lesions. J Pathol Nepal. 2014;4(8):654-657. doi:10.3126/jpn.v4i8.11593

24. Tahoun N, Ezzat N. Diagnostic accuracy and pitfalls of preoperative fine needle aspiration cytology in salivary gland lesions. J Egypt Natl Cancer Inst. 2008;20(4):358-368.

25. Piccioni LO, Fabiano B, Gemma M, Sarandria D, Bussi M. Fineneedle aspiration cytology in the diagnosis of parotid lesions. Acta Otorhinolaryngol Ital. 2011;31(1):1.

26. Fernandes GC, Pandit AA. Diagnosis of salivary gland tumors by FNAC. Young. 2000;59(96.60):50-87.

27. Joseph TP, Joseph CP, Jayalakshmy PS, Poothiode U. Diagnostic challenges in cytology of mucoepidermoid carcinoma: report of 6 cases with histopathological correlation. J Cytol Indian Acad Cytol. 2015;32(1):21-24. doi:10.4103/0970-9371.155226

28. Cohen MB, Fisher PE, Holly EA, Ljung B-M, Löwhagen T, Bottles $\mathrm{K}$. Fine needle aspiration biopsy diagnosis of mucoepidermoid carcinoma. Statistical Analysis Acta Cytol. 1989;34(1):43-49.

29. Schmidt RL, Hall BJ, Wilson AR, Layfield LJ. A systematic review and meta-analysis of the diagnostic accuracy of fine-needle aspiration cytology for parotid gland lesions. Am J Clin Pathol. 2011;136 (1):45-59. doi:10.1309/AJCPOIE0CZNAT6SQ
30. Kumar S, Permi HS, Paramesha K, et al. Role of Fine needle aspiration cytology in salivary gland tumours in correlation with their histopathology: a two year prospective study. J Clin Diag Res. 2011;5(7):1375-1380

31. Postema RJ, van Velthuysen MLF, van den Brekel MWM, et al. 113 AJM, Peterse JL. Accuracy of fine needle aspiration cytology of salivary gland lesions in the Netherlands Cancer Institute. Head Neck. 2004;26:418-424.

32. Tessy PJ, Jayalekshmy PS, Cicy PJ. Fine needle aspiration cytology of salivary gland lesions with histopathological correlation-a two year. J Healthc Biomed Res. 2015;3(04):91-99.

33. Orell SR, Sterrett GF. Head and neck; salivary glands. In: Orell and Sterrett's Fine Needle Aspiration Cytology. 5th ed. Elsevier; 2012:3976.

34. Tani E, Skoog L. Salivary glands and rare head and neck lesions. Bibbo M, Wilbur DC, editors. Comprehensive Cytopathology. 3rd ed. Elsevier; 2008:607-632.

35. Kocjan G, Shah KA. Salivary Glands. 3rd ed. Gray W, Kocjan G, editors. Elsevier; 2010:231-252.

36. Layfield LJ, Gopez EV. Cystic lesions of the salivary glands: cytologic features in fine-needle aspiration biopsies. DiagnCytopathol. 2002;27(4):197-204.

37. Krane JF, Faquin WC, Salivary Gland. Cibas ES, Ducatman BS, editors. Cytology Diagnostic Principles and Clinical Correlates: 4th ed. Saunders; 2014:299-332.

38. Klijanienko J, Vielh P. Fine-needle sampling of salivary gland lesions III. Cytologic and histologic correlation of 75 cases of adenoid cystic carcinoma: review and experience at the Institute Curie with emphasis on cytologic pitfalls. Diagn Cytopathol. 1997;17(1):36-41.

39. Handa U, Dhingra N, Chopra R, Mohan H. Pleomorphic adenoma: cytologic variations and potential diagnostic pitfalls. Diagn Cytopathol. 2009;37(1):11-15.

40. Jo HJ, Ahn HJ, Jung S, Yoon H-K. Diagnostic difficulties in fine needle aspiration of benign salivary glandular lesions. Korean J Pathol. 2012;46(6):569-575. doi:10.4132/KoreanJPathol.2012.46.6.569
Pathology and Laboratory Medicine International

\section{Publish your work in this journal}

Pathology and Laboratory Medicine International is a peer-reviewed, open access journal focusing on innovative basic research and translational research related to pathology or human disease. The journal includes original research, updates, case reports, reviews and commentaries on current controversies. The manuscript management system is completely online and includes a very quick and fair peer-review system. Visit http://www.dovepress.com/testimonials.php to read real quotes from published authors. 